\title{
Distributions and Fluxes of Nitrogen and Phosphorus Nutrients in Porewater Sediments in the Estuary of Jepara Indonesia
}

\author{
Lilik Maslukah*, Sri Yulina Wulandari', Indra Budi Prasetyawan'1, Muhammad Zainuri' \\ 1 Department of Oceanography, Faculty of Fisheries and Marine Sciences, Diponegoro University, \\ Jl. Prof. Soedarto, SH., Semarang 50275, Indonesia \\ * Corresponding author's e-mail: lilik_masluka@yahoo.com
}

\begin{abstract}
River is a location that is responsible for the main transport of nutrient flow from land to estuary and oceans. The nutrients that are adsorbed by the solid phase can be deposited and stored in the sediment. Sediments in estuaries and beaches have an important role in storing or removing nutrients from or to the water column. The presence of nutrients in porewater interacts with sediment and water column. In general, the nutrients that have a role as limiting factors for life in the waters are nitrogen $(\mathrm{N})$ and phosphorus $(\mathrm{P})$. The release of $\mathrm{N}$ and $\mathrm{P}$ elements is very important for the estuary and coastal environment, related to the process of regenerating nutrients into the water column. The release mechanism is determined by a diffusion process, based on the difference of concentration between the water column and the porewater. This study aims to determine the concentration of $\mathrm{N}$ and $\mathrm{P}$ in the porewater and estimate the value of flux. The sediment samples were taken from the Wiso and Serang estuary, Jepara. The components that were analyzed in the porewater are the concentration of $\mathrm{N}$ (nitrate, nitrite) and $\mathrm{P}$ (phosphate). Nitrite, nitrate and phosphate were determined by using sulphanilamide method and the molybdenum blue method, respectively. Furthermore, the flux value (F) was calculated based on the Fick's I Law which was corrected by porosity. The results show that the mean concentrations of nitrate $\left(\mathrm{NO}_{3}^{-}\right)$, nitrite $\left(\mathrm{NO}_{2}^{-}\right)$and phosphate $\left(\mathrm{PO}_{4}^{2-}\right)$ in the sediment water of Serang Estuary are 1.96, 1.41, 3.46 $\mu \mathrm{M}$ and in the Wiso estuary are 3.4, 1.85, 8.22 $\mu \mathrm{M}$. In general, based on the calculation of flux, the sediments in the Serang and Wiso estuaries have a positive flux. Moreover, the sediment in Jepara acts as a source and releases N and P nutrient into the water column. The Wiso estuary has a higher flux than the Serang estuary.
\end{abstract}

Keywords: porewater, sediment flux, N, P nutrient, Jepara

\section{INTRODUCTION}

The growth of population, rapid economic development in urban areas and increasing intensive use of agricultural land cause an increasing of pollution that has a significant impact on the aquatic environment (Zhang et al., 2009), estuaries and oceans (Zhang et al., 2014). This nutrient input will affect the ecosystem structure, resulting in the environmental damage, change in biogeochemical processes and high productivity (Halpen et al., 2008 and Qu 2009).

Common nutrients that are the limiting factors for life in the waters are nitrogen $(\mathrm{N})$ and phosphorus (P). River flows are a major source of $\mathrm{N}$ and $\mathrm{P}$ to coastal waters and have an important role in stimulating biological processes in the waters (Gypens et al., 2009) which included the increasing of phytoplankton growth (Carter et al., 2005). The high concentrations of nutrients in aquatic environments have a positive influence, because the phytoplankton production becomes higher. In the later stages, it will affect the fish production (Jones-Lee and Lee, 2005). On the other hand, the negative impacts are the decreasing dissolved oxygen, the development of dangerous phytoplankton or algae (Howart, 2000) and the changing species composition (PRED, 2009).

The Jepara waters have fresh water supply from several rivers that are characterized by different areas and human activities. The existence of this river acts as a supplier of nutrients to the 
waters. The result of the research conducted by Maslukah (2016) stated that the existence of the Pasokan River, Grenjengan Mlonggo, Wiso and Serang rivers contributed the nutrients N, P to the Jepara waters of 29.56 ton N / month and 2.11 ton $\mathrm{P} /$ month where the Serang River was the most contributed to. As a result, the waters of Jepara, which is close to the Serang River, became more fertile so the primary productivity is quite high.

The excess of nutrients from the external inputs can be deposited in the sediment through the adsorption poses from the dissolved phase. The sediments in the estuary and coast have an important role in the environment in terms of storing or releasing chemical compounds from or to the water column (Brigolin et al. 2011; Wallman et al. 2008 ; Jin et al. 2012 ; Zhang et al., 2014). The release of $\mathrm{N}$ and $\mathrm{P}$ elements is very important for the estuary and coastal environment, related to the process of regenerating nutrients into the water column. The release mechanism is determined by the diffusion process, based on the difference in the concentration between the water and pore columns (Callender and Hammond, 1982) as well as by oceanic processes such as currents and tides (Warken et al., 2000 and Maslukah et al., 2014). The grain size distribution and environmental parameters such as depth, salinity, $\mathrm{pH}$ and dissolved oxygen play a role in controlling the release process of nutrients.

Several studies on the $\mathrm{N}$ and $\mathrm{P}$ nutrients in porewater were in some estuaries such as Bohai Bay, China (Mu et al., 2016), Yalujiang Estuary (He et al., 2002), Seto Estuary, Japan (Magni \& Montani, 2006) and Gulf of St. Lawrence (Thibodeau et al., 2010). Moreover, the research relating to the flux was done by Robledo et al. (2016) and Mu et al. (2017). The research on flux is mostly done with a simulation in the laboratory, but still limited based on the calculation directly in the field. The information related to porewater and its flux based on the field data, especially in the waters of Jepara, have never been investigated before.

Given the importance of sediments in storing chemical elements, it is necessary to know the role of sediments in terms of supplying nutrients to the water column. This study aims to determine the horizontal distribution of $\mathrm{P}$ in porewater and the flux value in the two different estuaries.

\section{MATERIALS AND METHODS}

\section{Research Location}

This research was located in two river estuaries, i.e. Wiso River Estuary/W1-W10 (located at the coordinate point of $110^{\circ} 37^{\prime} 18^{\prime \prime}-110^{\circ} 35^{\prime} 31^{\prime \prime}$ E and 6 42 '27 " - 6 $41^{\prime} 18,2^{\prime}$ 'S) and Serang River Estuary/S1-S10 (at coordinate point of $110^{\circ} 34^{\prime} 57^{\prime \prime}$ $-110^{\circ} 37^{\prime} 19^{\prime \prime} \mathrm{E}$ and " - 639'47 -6042'30 ' 'S). Determination of research locations was conducted by purposive sampling method which refers to the previous research (Maslukah et al., 2016). Each location was divided into 10 stations with consideration i.e. station 1 in the river, station 2 and 3 at the mouth of the river, and stations 4 to 10 in the coastal waters.

\section{Sediment Sampling}

The sediment samples were taken using a sediment grab $( \pm 25 \mathrm{~cm}$ depth). The samples were put in a coolbox. Then, in a laboratory, the porewater was extracted by centrifugation (4000 rpm) $\mathrm{Mu}$ et 1.. (2017) to analyse the $\mathrm{N}$ and P. The concentrations of nitrite were determined by using the sulphanilamide method (Wetzel \& Likens, 1991) and nitrate using UV Spectrophotometry in wavelength $270 \& 230$, respectively. The P nutrient in porewater was determined as orthophosphate using the ascorbit acid method (APHA, 1992). The absorbance values of these two nutrients were determined using Shimadzu 3600 UV-VIS spectrophotometer, with a $1 \mathrm{~cm}$ wide cuvet.

\section{Data Analysis}

The patterns of porewater distribution of $\mathrm{N}$ and $\mathrm{P}$ in each estuary were described. The flux value (F) was calculated under Fick's I law corrected by porosity, with equation 1 .

$$
F=-\varnothing D d C / d z
$$

where: $d C / d z=$ vertical gradient (difference of concentration between water columns and $2.5-5 \mathrm{~cm}$ of interstitial water)

$D=$ diffuse coefficient $\left(\mathrm{N}=19.8 \cdot 10^{-6}\right.$ $\mathrm{cm}^{2} / \mathrm{s}, \mathrm{PO} 4=7,25 \cdot 10^{-6} \mathrm{~cm}^{2} / \mathrm{s}$ )

$\varnothing=$ porosity of the sediments was determined by drying the sediment at $90^{\circ} \mathrm{C}$ for 24 hours. Loss of weight divided by wet weight is called $\varnothing$ (Coredor and Morrel, 1985). 


\section{RESULTS AND DISCUSSION}

The concentration of nitrate $\left(\mathrm{NO}_{3}\right)$, nitrite $\left(\mathrm{NO}_{2}\right)$ and phosphate $\left(\mathrm{PO}_{4}^{2-}\right)$ in the sediment water of the Serang Estuary ranged from $0.3166-6.5353 \mu \mathrm{M}$ (mean of $1,9611 \pm 1.8491$ ), $1.0082-2,1948 \mu \mathrm{M}$ (mean of $1.4097 \pm 0.3990)$ and $2.6722-4,6854 \mu \mathrm{M}$ (mean of $3,4620 \pm 6,8644$ ), respectively. On the other hand, in the Wiso estuary, nitrate is in the range of $1,1297-6,6653 \mu \mathrm{M}$ (mean 3,4123 $\pm 1,7990$ ), nitrite ranged between $1.0288 \mu \mathrm{Mand} 2,8417 \mu \mathrm{M}$ (meanof $1,8474 \pm 0,5148$ ) and phosphate between $3.2118 \mu \mathrm{M}$ and 27.5812 $\mu \mathrm{M}$ (mean $8.2226 \pm 7.2620)$. The data are presented in Table 1.

The resuls of thet research by Garcia-Robledo (2016) that was conducted in a Cadiz Bay (Spain) showed that the concentration of nitrate and phosphate in porewater are $28.4 \mu \mathrm{M}$ and $9.2 \mu \mathrm{M}$, while in the research conducted by Zhang et al. (2014), nitrates were found in the range between $0.42 \mu \mathrm{M}$ and $29.76 \mu \mathrm{M}$. Moreover, the phosphate in the range of $0.06-3.36 \mu \mathrm{M}$ in summer and DIN $\left(\mathrm{NO}_{3+2}-\mathrm{N}\right)$ at Pearl River Estuary (PRE) reached $5.23 \mu \mathrm{M}$ and in Yalujiang Estruary reached $3 \mu \mathrm{M}$ (Ye et al., 2002). The comparison of nitrate and phosphate concentrations from other regions is presented in Table 2.
On the basis of Table 2, the Wiso estuary has a higher nutrient concentration in porewater than the Serang estuary. Maslukah (2017) stated that the high concentration of dissolved $\mathrm{N}$ and $\mathrm{P}$ nutrients in the Wiso river estuary is closely related to its location in the urban center of Jepara Regency. The presence of nutrient concentrations in porewater is largely determined by the grain size distribution and organic matter. On the basis of research it was determined that the Wiso waters have sand fractionation, with more than 92\% (except in station W6) and the Serang waters have sediment fractionation in which silt and clay are more dominant. The Wiso estuary also has a higher organic content. Magni and Montani (2006) stated that high organic matter in sediment can affect the nutrient concentration in the porewater. The data are presented in Table 3.

On the basis of the difference of concentration between surface water column to sediment water, the flux value was then calculated from each research station. The flux with a positive value means that there is a sediment input to the water column; if the value is negative, it is otherwise. The results show that the sediments of Serang and Wiso Estuaries contribute to the nutrient concentration of the water column. In the mouth of the Wiso River, there is a great flux value

Table 1. N, P concentrations in sediment / porewater $(\mu \mathrm{M})$

\begin{tabular}{|c|c|c|c|c|}
\hline Stations & Phospor & Nitrate & Nitrite & ${\text { DIN }\left(\mathrm{NO}_{3+2}-\mathrm{N}\right)}^{* *}$ \\
\hline s1 & $* *$ & 0.7499 & 1.0082 & 1.7581 \\
\hline s2 & 2.7766 & 2.5195 & 1.3964 & 3.9159 \\
\hline s3 & 2.6722 & 6.5353 & 1.8321 & 8.3675 \\
\hline s5 & 4.6855 & 0.8909 & 1.5447 & 2.4356 \\
\hline s6 & 3.5894 & 1.3510 & 1.0889 & 2.4400 \\
\hline s7 & 2.7312 & 2.1954 & 1.1163 & 3.3118 \\
\hline s8 & 2.8182 & 1.6628 & 1.0779 & 2.7407 \\
\hline s9 & 2.9164 & 0.3166 & 2.1948 & 2.5115 \\
\hline s10 & 4.6137 & 1.4283 & 1.4279 & $3.3780 \pm 1.9688$ \\
\hline Average & 4.3552 & $1.9611 \pm 1.8491$ & $1.4097 \pm 0.3990$ & 8.2734 \\
\hline w1 & 8.1861 & 6.6653 & 1.6080 & 3.8695 \\
\hline w2 & 4.7585 & 2.2840 & 1.5856 & 5.3257 \\
\hline w3 & 4.6936 & 3.1069 & 2.2188 & 7.0419 \\
\hline w4 & 5.1904 & 4.8948 & 2.1471 & 3.9714 \\
\hline w5 & 6.2461 & 1.1297 & 2.8417 & 4.1179 \\
\hline w6 & 5.1543 & 2.2214 & 1.8965 & 2.6043 \\
\hline w7 & 12.3111 & 1.5755 & 1.0288 & 7.1084 \\
\hline w8 & 27.5812 & 5.0821 & 2.0263 & 6.4699 \\
\hline w9 & 4.8931 & 4.6144 & 1.8554 & 3.8147 \\
\hline w10 & 3.2118 & 2.5487 & 1.2660 & $\mathbf{5 . 2 5 9 7 \pm 1 . 8 6 1 3}$ \\
\hline Average & $\mathbf{8 . 2 2 2 6 \pm 7 . 2 6 2 0}$ & $\mathbf{3 . 4 1 2 3 \pm 1 . 7 9 9 0}$ & & \\
\hline
\end{tabular}

** no data. 
Table 2. The concentrations of porewater nutrient at some regions in the world $(\mu \mathrm{M})$

\begin{tabular}{|l|c|c|c|}
\hline \multicolumn{1}{|c|}{ Stations } & $\mathrm{DIN}\left(\mathrm{NO}_{2+3}-\mathrm{N}\right)$ & $\mathrm{PO}_{4}-\mathrm{P}$ & Source \\
\hline Gulf of St. Lawrence & $2.3-27.5$ & $2-20$ & Thibodeau et. al (2010) \\
\hline Seine Estuary & - & $210.5-631.6$ & Bally et. al.(2005) \\
\hline Equatorial Northeastern Pasific & $25.8-38.5$ & $1.2-2.5$ & Ni et. al (2005) \\
\hline Cape Cod Bay & & $0-100$ & Hopkinson et. al. (2001) \\
\hline Gulf of Lions & $5.6-17.0$ & $0.15-4$ & Hu et. al (2006) \\
\hline Southern Oceans & $3.0-58.6$ & - & Ye et. al. (2002) \\
\hline Yalujiang Estuary & 3.0 & $0.8-70.4$ & He et. al. (2002) \\
\hline Day a Bay & $30-230$ & $23-80$ & Zhang et. al. (2014) \\
\hline PRE & 5.2 & 1.9 & Mu et. al (2017) \\
\hline Bohai Bay, China & $8.28-55.9$ & $0.320-1.68$ & This study \\
\hline Coast of Jepara, Indonesia & $1.76-8.37$ & $2.67-27.58$ & \\
\hline
\end{tabular}

Table 3. Distribution of grain size and total organic carbon (TOC) in sediment

\begin{tabular}{|c|c|c|c|c|c|}
\hline Stations & Sand $(\%)$ & Silt (\%) & Clay (\%) & Mud (\%) & TOC (\%) \\
\hline W1 & 96.30 & 1.71 & 1.99 & 3.7 & 0.19 \\
\hline W2 & 97.71 & 0.92 & 1.37 & 2.29 & 0.24 \\
\hline W3 & 94.25 & 1.77 & 3.98 & 5.75 & 0.19 \\
\hline W4 & 92.89 & 6.88 & 0.23 & 7.11 & 0.16 \\
\hline W5 & 98.35 & 1.53 & 0.12 & 1.65 & 0.12 \\
\hline W6 & $* *$ & $* *$ & $* *$ & $* *$ & 0.33 \\
\hline W7 & 49.38 & 48.46 & 2.16 & 50.62 & 0.71 \\
\hline W8 & 94.98 & 4.98 & 0.04 & 5.02 & 0.24 \\
\hline W9 & 99.53 & 0.38 & 0.09 & 0.47 & 0.18 \\
\hline W10 & 95.03 & 4.94 & 0.03 & 4.97 & 0.21 \\
\hline S1 & ** & $* *$ & $* *$ & $* *$ & $* *$ \\
\hline S2 & 2.71 & 58.03 & 39.26 & 97.29 & 0.11 \\
\hline S3 & 4.67 & 51.74 & 43.59 & 95.33 & 0.11 \\
\hline S4 & 10.05 & 56.58 & 33.38 & 89.96 & 0.07 \\
\hline S5 & 10.00 & 59.96 & 30.05 & 90.01 & 0.12 \\
\hline S6 & 13.58 & 60.02 & 26.40 & 86.42 & 0.13 \\
\hline S7 & 12.06 & 59.69 & 28.26 & 87.95 & 0.27 \\
\hline S8 & 10.06 & 60.00 & 29.94 & 89.94 & 0.16 \\
\hline S9 & 7.31 & 62.12 & 30.57 & 92.69 & 0.17 \\
\hline $\mathrm{S} 10$ & 10.07 & 57.24 & 32.69 & 89.93 & 0.21 \\
\hline
\end{tabular}

** no data; S (Serang); W (Wiso).

compared to the mouth of the Serang river. The mean values were $21.88 \mathrm{mmol} \cdot \mathrm{m}^{-2} \cdot \mathrm{d}^{-1}$ for total $\mathrm{N}\left(\mathrm{NO}_{3+2}\right)$ and $5.08 \mathrm{mmol} \cdot \mathrm{m}^{-2} \cdot \mathrm{d}^{-1}$ for phosphate, while in the Serang estuary, the average flux value is $13.21 \mathrm{mmol} . \mathrm{m}^{-2} \cdot \mathrm{d}^{-1}$ for $\mathrm{N}$ and $13.13 \mathrm{mmol} \cdot \mathrm{m}^{-2} \cdot \mathrm{d}^{-1}$ for $\mathrm{P}$. These data are shown in Table 4.

Table 4 indicates there are several stations that have negative values. This means that the station has no nutrient input from the water column to the sediment. The sediment functions as a nutrients sink from the water column, while the sediments that have positive values play a role as a source of nutrients for the upper water column (Zhang et al., 2014). The distribution patterns of each nutrient, i.e. nitrate, the total $\mathrm{N}\left(\mathrm{NO}_{3+2}\right)$ and sediment phosphates are shown in Figure 1.

\section{CONCLUSION}

The results show the concentrations of $\mathrm{N}$ and $\mathrm{P}$ (mean \pm standard deviation) in the porewater for nitrate, nitrite, and phosphate in the sediment water of Serang Estuary were $1.9611 \pm$ $1.8491 \mu \mathrm{M}, 1.4097 \pm 0.3990 \mu \mathrm{M}$ and $3,4620 \pm$ $6.8644 \mu \mathrm{M}$, respectively, while for the Wiso Estuary in the range of $3,4123 \pm 1,7990 \mu \mathrm{M}, 1,8474$ $\pm 0,5148 \mu \mathrm{M}$ and $8,2226 \pm 7,2620 \mu \mathrm{M}$, respectively. The results pertaining to the flux value calculations of the sediments for the two sites show a value of $\mathrm{N}$ nutrient is not high. The $\mathrm{N}$ fluxes from sediments of Serang and Wiso estuary were $20.5 \mathrm{~kg} \cdot \mathrm{m}^{-2} \cdot \mathrm{s}^{-1}$ and $21.21 \mathrm{~kg} \cdot \mathrm{m}^{-2} \cdot \mathrm{s}^{-1}$, P flux sequen- 
Table 4. Fluxes of N,P in Serang and Wiso estuaries

\begin{tabular}{|c|c|c|c|c|c|c|}
\hline Stations & $\mathrm{dC}$ & Porosity & $\begin{array}{l}\text { Nitrate Flux mmol.m- } \\
\qquad \begin{array}{l}\left.{ }^{-} \cdot d^{-1}\right)\end{array}\end{array}$ & $\begin{array}{l}\text { Nitrite Flux (mmol. } \mathrm{m}^{-} \\
\left.{ }^{2} \cdot \mathrm{d}^{-1}\right)\end{array}$ & $\begin{array}{l}\text { DIN Flux }\left(\mathrm{mmol} . \mathrm{m}^{-}\right. \\
\left.{ }^{2} \cdot \mathrm{d}^{-1}\right)\end{array}$ & $\begin{array}{c}\text { Phosphor } \\
\text { Flux } \\
\left(\mathrm{mmol} \cdot \mathrm{m}^{-2} \cdot \mathrm{d}^{-1}\right)\end{array}$ \\
\hline w1 & 4.85 & 0.31 & 7.64 & 1.50 & 9.14 & 4.75 \\
\hline w2 & 0.68 & 0.30 & 1.00 & 1.34 & 2.33 & 2.09 \\
\hline w3 & 2.03 & 0.28 & 21.14 & 13.51 & 34.66 & 1.98 \\
\hline w4 & 3.75 & 0.26 & 35.14 & 18.32 & 53.45 & 2.13 \\
\hline w5 & 0.001 & 0.23 & 0.01 & 16.33 & 16.34 & 1.98 \\
\hline w6 & 1.13 & 0.35 & 2.31 & 5.40 & 7.71 & 3.79 \\
\hline w7 & 0.49 & 0.48 & 1.86 & 6.49 & 8.35 & 17.61 \\
\hline w8 & 3.89 & 0.26 & 4.30 & 0.91 & 5.21 & 11.63 \\
\hline sw9 & 2.61 & 0.27 & 27.75 & 1.82 & 29.57 & 2.04 \\
\hline w10 & 1.41 & 0.39 & 35.15 & 4.20 & 39.34 & 2.83 \\
\hline Average & 2.08 & 0.313 & 14.29 & 7.59 & 21.88 & 5.08 \\
\hline S1 & ** & ** & ** & $* *$ & ** & $\star *$ \\
\hline S2 & -0.99 & 0.50 & -4.08 & -0.07 & -4.15 & 3.03 \\
\hline S3 & 0.78 & 0.48 & 2.92 & 1.38 & 4.30 & 3.25 \\
\hline S4 & 5.39 & 0.28 & 61.91 & 1.62 & 63.53 & 2.26 \\
\hline S5 & -0.35 & 0.37 & -6.94 & 3.02 & -3.92 & 2.98 \\
\hline S6 & 0.34 & 0.44 & 1.05 & 2.62 & 3.67 & 3.00 \\
\hline S7 & 1.14 & 0.46 & 3.91 & 3.18 & 7.09 & 3.42 \\
\hline S8 & 0.64 & 0.50 & 2.65 & 3.71 & 6.36 & 4.09 \\
\hline S9 & -0.68 & 0.28 & 35.15 & 2.68 & 37.83 & 2.23 \\
\hline S10 & 0.43 & 0.39 & 1.08 & 3.11 & 4.19 & 3.95 \\
\hline Average & 0.75 & 0.41 & 10.85 & 2.36 & 13.21 & 3.13 \\
\hline
\end{tabular}

** no data.

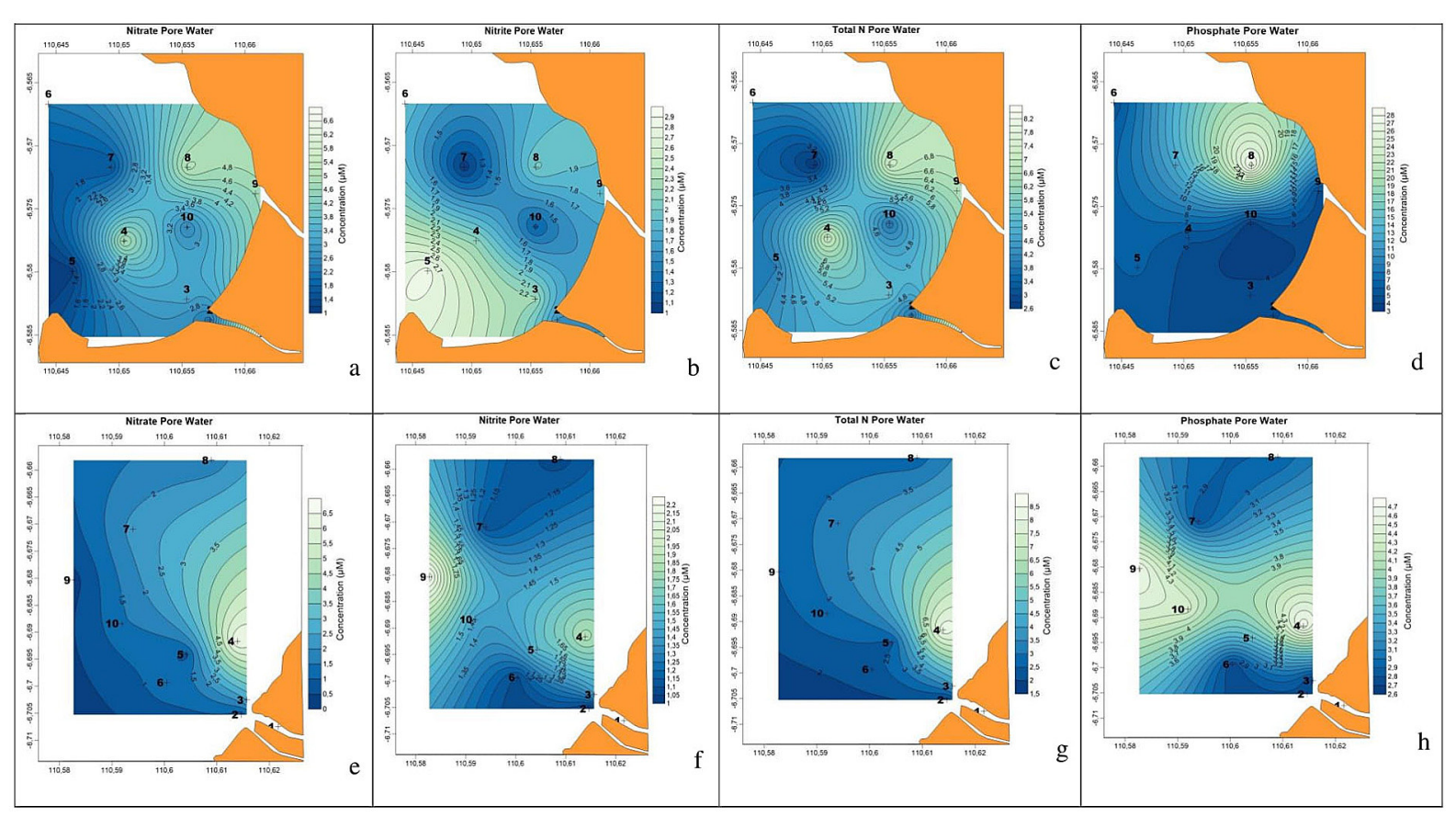

Figure 1. Map of Nitrate, Nitrite, $\mathrm{N}$ total and Phosphate distribution patterns in porewater sediment of Wiso (a, b, c, d) and Serang (e, f, g, h) estuaries

tially was $22.36 \mathrm{~kg} \cdot \mathrm{m}^{-2} \cdot \mathrm{s}^{-1}$ and $34.74 \mathrm{~kg} \cdot \mathrm{m}^{-2} \cdot \mathrm{s}^{-1}$. The Wiso Estuary is located in the urban center that received higher nutrient input of N, P so the result of flux value is higher than in the Serang
Estuary. On the other hand, the high flux value at the mouth of the Wiso River is influenced by the grain size of the rougher sediment (percentage of sand size $>90 \%$ ) and higher organic matter. 


\section{Acknowledgements}

We would like to thank Research Institutions and Community Service of Diponegoro University for funding our research from RPP program [No: SP DIPA -042.01.2.400898/2016].

\section{REFERENCES}

1. APHA. 1992. Standard method for the examination of water and wastewater. 18th edition. Washington, 252p.

2. Bally G., Mesnage V., Deloffre J., Clarisse O., Lafite R., Dupont J.P. 2004. Chemical characterization of porewaters in an intertidal mudflat of the Seine Estuary: relationship to erosion-deposition cycles. Marine Pollution Bulletin, 49(3), 163-173.

3. Brigolin D., Lovato T., Rubino A., and Pastres R. 2011. Coupling early-diagenesis and pelagic biogeochemical models for estimating the seasonal variability of $\mathrm{N}$ and $\mathrm{P}$ fluxes at the sediment water interface: application to the NorthWestern Adriatic coastal zone. J. Marine Syst., 87, 239-255.

4. Callender E., Hammond D.E. 1982. Nutrient exchange across the sediment-water interface in the Potomac river estuary. Estuar Coast Shelf Sci., 33, 395-413.

5. Carter C.M., Ross A.H., Schiel D.R., Williams C.H., and Hayden B. 2005. In situ microcosm experiment on the influence of nitrate and light on phytoplankton community composition. J. Exp. Mar. Biol. Ecol., 326, 1-13.

6. Corredor J.E, Morell J.1985. Inorganic nitrogen in coral reef sediments. Mar Chem. 16, 379-384.

7. Denis L., Grenz C. 2003. Spatial variability in oxygen and nutrient fluxes at the sediment-water interface on the continental shelf in the Gulf of Lions (NW Mediterranean). Oceanologica Acta, 26(4), 373-389.

8. Gypens N., Borges A.V., and Lancelot, C. 2009. Effect of eutrophication on air-sea $\mathrm{CO} 2$ fluxes in the coastal Southern North Sea: a model study of the past 50 years. Global Change Biology, 15, 1040-1056.

9. Halpern B.S., Walbridge S., Selkoe KA., Kappel C.V., Micheli F., D’Agrosa C., Bruno J. F., Casey K.S., Ebert C., Fox H.E., Fujita R., Heinemann D., Lenihan H.S., Madin E.M., Perry M.T., Selig E.R., Spalding, M., Steneck R., and Watson R. 2008. A global map of human impacts on marine ecosystems. Science, 319, 948-952.

10. He T., Xie J., Yu H.S., Fang H., and Gao Q. 2008. The distribution of nutrients in the interstitial water and overlying water in Daya Bay. Acta Scientiae Circumstantiae, 28(11), 2361-2368.
11. Hopkinson Jr.C.S., Giblin A.E. and Tucker J. 2001. Benthic metabolism and nutrient regeneration on the continental shelf of Eastern Massachusetts, USA. Marine Ecology Progress Series, 224, 1-19.

12. Howarth R., Anderson D., Cloern J., Elfring C., Hopkinson C., Lapointe B., Malone T., Marcus N., Mc Glathery K., Sharpley A., and Walker D. 2000. Nutrient pollution of coastal rivers, bays, and seas. Issue in Ecology, 7, 1 -15.

13. Hu C.Y., Pan J.M., Liu X.Y., et al., 2006. Study on distribution and benthic fluxes of nutrients in sediment interstitial water of the Southern Ocean. Acta Oceanologica Sinica, 28(4), 102-107. (in Chinese with English Abstract).

14. Jia J.J., Gao J.H., Liu Y.F., Gao S., and Yang Y. 2012. Environmental changes in Shamei Lagoon, Hainan Island, China : Interactions between natural processes and human activities. J. Asian Earth Sci., 52, 158-168.

15. Jin X., He Y., Kirumba G., Hassan Y., and Li J. 2013. Phosphorus fractions and phosphate sorption-release characteristics of the sediment in the Yangtze River estuary reservoir. Ecological Engineering, 55, 62-66.

16. Jones-Lee A., Lee G.F. 2005. Eutrophication (excessive fertilization).water encyclopedia: surface and agricultural water. Wiley, Hoboken, NJ. pp. 107-114.

17. Magni P and Montani S. 2006. Seasonal patterns of pore-water nutrients, benthic chlorophyll a and sedimentary AVS in a macrobenthos-rich tidal flat. Hydrobiologia, 571, 297-311.

18. Maslukah L., Indrayanti E. and Rifai A. 2014. Sebaran material organik dan zat hara oleh arus pasang surut di muara sungai Demaan, Jepara. Ilmu Kelautan, 19 (4), 189-194.

19. Maslukah L., Wulandari S.Y., and Prasetyawan I.B. 2016. Kontribusi nutrien $\mathrm{N}$ dan $\mathrm{P}$ dari sungai Serang dan Wiso ke perairan Jepara. Prosiding seminar nasional hasil-hasil penelitian perikanan dan kelautan ke-VI. Fakultas Perikanan dan Ilmu Kelautan - Pusat Kajian Mitigasi Bencana dan Rehabilitasi Pesisir, Undip. Pp. 183-191.

20. Maslukah L., Wulandari S.Y., and Setyawan I.B. 2017. Konsentrasi klorofil-a dan keterkaitannya dengan nutrient N, P di Perairan Jepara : Studi Perbandingan Perairan Muara Sungai Wiso dan Serang. Jurnal Kelautan Tropis, 20 (2), 72-77.

21. Mu D., Yuan D., Feng H., Xing F., Teo F.Y., and Li S. 2017. Nutrient fluxes across sediment-water interface in Bohai Bay Coastal Zone, China. Marine Pollution Bulletin, 114, 705-714.

22. Ni J.Y., Maggiulli M., Liu X. Y., et al., 2005. Pore water distribution and quantification of diffusive benthic fluxes of silicate, nitrate and phosphate in surface sediments of the Equatorial Northeastern Pacific. Geochimica, 34(6), 587-594. 
23. PREP. 2009. State of the estuaries report. piscataqua region estuaries partnership, University of New Hampshire, Durham, NH. Published online on : www.prep.unh.edu/resources/pdf/2009_state_ of_the-prep-09.pdf.

24. Qu T., Song Y. T. and Yamagata T. 2009. An introduction to the South China Sea throughflow: Its dynamics, variability, and application for climate. Dyn. Atmos. Oceans., 47, 3-14.

25. Robledo G., Bohorquez E. Corzo A., JimenezArias J.L., and Papaspyrou, S. 2016. Dynamics of inorganic nutrients in intertidal sediments: porewater, exchangeable, and intracellular pools. Frontier in microbiology (7), 1-14.

26. Thibodeau B., Lehmann M. F., Kowarzyk J., Mucci A., Gelinas Y., Gilbert D., Maranger R., and Alkhatib M. 2010. Benthic nutrient fluxes along the Laurentian Channel: Impacts on the $\mathrm{N}$ budget of the St. Lawrence marine system. Estuarine, Coastal and Shelf Science, 90(4), 195-205.

27. Wallman K., Aloisi G., Haeckel M., Tishchenko P., Pavlova G., Greinert J., Kutterolf S., Eisen- haver A. 2008. Silicate weathering in an oxic marine sediments. Geochim.Cosmochim.Acta., 72, 2895-2918.

28. Warnken K., Gill G.A., Santschi P.H. and Griffin L.L. 2000. Benthic exchange of nutrients in Galveston Bay, Texas. Estuaries, 23(5), 647-661.

29. Wetzel R.G. and Likens G.E. 1991. Limnological analysis, 2nd.edn. Springer-Verlag, New York.

30. Ye X.W., Liu S.M., and Zhang J. 2002. Nutrients in sediment pore water in tidal flat area in Yalujiang Estuary. Environmental Science, 23(3), 92-96.

31. Zhang L., Yin K.D., Wang L., Chen F., Zhang D. and Yang Y. 2009. The sources and accumulation rate of sedimentary organic matter in the Pearl River Estuary and Adjacent Coastal Area, Southern China. Estuarine, Coastal and Shelf Science, 85(2), 190-196.

32. Zhang L., Wang K., Yin Y., Lü Y., Yang X., and Huang. 2014. Spatial and seasonal variations of nutrients in sediment profiles and their sedimentwater fluxes in the Pearl River Estuary, Southern China. Journal of Earth Science, 25(1), 197-206. 